Jost, I. 1908. Vorlesungen über Pflanzenphysiologie. 2nd ed. Gustav Fischer, Jena.

KerL, FR. 1912. Beiträge zur Physiologie der farblosen Schwefelbakterien. Beitr. Biol. Pflanzen 11: 335-372.

$T_{A A}$ Rivisere, J. W. M. 1963. Cultivation and properties of Thiovulum majus Hinze, p. 61-72. In C. H. Oppenheimer [ed.], Symposium marine microbiology. Charles C. Thomas, Springfield, Ill.

TARSEN, H. 1960. Chemosynthesis, p. 63-648. In W. W. Ruhland [ed.], Handbuch Pfanzenphysiologic. Bd. V, Teil 2. Springer, Berlin, Göttingen, Heidelberg.

Pringshem, E. G. 1949. Iron bacteria. Biol. Rev. Cambridge Phil. Soc. 24: 200-245.

- 1963. Farblose Algen, ein Beitrag zur Evolutionsforschung. Gustav Fischer, Stuttgart.

1964a. Heterotrophism and species concepts in Begaialoa. Amer. J. Bot. 51: 898-913.

___ 1964b. Entwicklung und biologische Bedeutung der Sexualität. Biol. ZtrbI. 83: 739-756.

1964c. Phasengrenzschichten als Wohnorte von Mikroorganismen. Nachr. Akad. Wiss., Göttingen.
No. 15: 207-209.

- AND U. Kowallik. 1964. Ist Beggialoa chemoautotroph? Naturwissenschaften 51: 492. - AND W. Wiessner. 1963. Minimum requirements for heterotrophic growth and reserve substance in Beggialoa. Nature 197: 102.

Schumacher, W. 1958. Teil II Physiologie, p. 175-332. In R. Harder et al. [ed.], Lehrbuch der Botanik für Hochschulen. 27th ed. Gustav Fischer, Stuttgart

- - 1962. Teil II Physiologie, p. 186-345. In $\mathrm{R}$. Harder et al. [ed.], Lehrbuch der Botanik für Hochschulen. 28th ed. Gustav Fischer, Stuttgart.

ScotTen, H. L., AND J. L. STokes. 1962 . Isolation and properties of Beggiatoa. Arch. Mikrohiol. 42: 353-368.

Thrmann, K. V. 1955. The life of bacteria, their growth, metabolism, and relationships. Macmillan, New York.

Wixogradsex, S. 1922. Eisenbakterien als Anorgoxidanten. Zentralbl. Bakterio]. (Abt. II) $57: 1$.

WooD, E. J. F. 1963. Heterotrophic microorganisms in the oreans. Ann. Rev. Oceanogr. Mar. Biol. 1: 197222

Amer. J. Bot. 53(8): 806i-816. 1966.

\title{
PHOTOPERIODIC ADAPTATION TO LATITUDE IN XANTHIUM STRUMARIUM ${ }^{1}$
}

\author{
Peter M. Ray and William E. Alexander \\ Department of Botany and Botanical Gardens, University of Michigan, Ann Arbor
}

\section{A B S T R A C T}

Photoperiodic responses of collections of Xanthium strumarium L., grown from seed obtained in nature at various localities in North America between latitudes $20^{\circ}$ and $45.5^{\circ} \mathrm{N}$, were examined. The critical night length was found to vary noticeably with latitude of origin, from about $7.5 \mathrm{hr}$ in the northernmost strains to above $10 \mathrm{hr}$ in the southern strains. These differences are considered to represent genetic adaptation of the reproductive system to environmental variables as a result of natural selection. Several strains showed a quantitative short day response rather than the more usual qualitative response. Strains from Hawaii exhibited a surprisingly tardy and erratic short-day response with a critical night length of about $11 \mathrm{hr}$, which may be an adaptation to a tropical climate.

A considerable amount of evidence has been obtained that photoperiodic responses in the vegetative development and reproduction of plants in

${ }^{1}$ Received for publication September $7,1965$.

This investigation was supported by a grant from the Rackham Graduate School of the University of Michigan (NSF Institutional Grant No. 31).

The anthors thank B. G. Kang for technical assistance. They are grateful to the following for collecting seed for them: J. T. Alexander, C. R. Bell, A. C. Buck, W. Chorney, R. Collins, O. Degener, S. L. Everist, R. E. Farmer, G. C. Gillett, R. Isaac, J. M. Kavanaugh, D. Lóve, C. McMillan, W. W. Payne, L. W. Plımmer, W. Reiman, J. J. Ruemmele, N. G. Sansing, N. Searle, M. E. Sparrow, E. Strong, W. Talbott, F. Tatum, E. G. Voss, and R. L. Wynn. They are especially indebted to Dr. Doris Löve for examining and annotating voncher specimens of plants used in this stidy.

2 Present address: Division of Natural Sciences, University of California, Santa Cruz 95060. nature vary genetically with lat'tude in such a way as to tend to adapt races of the species favorably to the different photoperiodic regimes that prevail at different latitudes. Studies in this area, reviewed recently by McMillan (1960), Vaartaja (1962) and Hiesey and Milner (1965), have dealt mainly with perennial herbs and woody plants. Relatively little investigation of adaptation of photoperiodic responses in annuals seems to have been made, even though one might expect that the selective pressure on photoperiodism in annuals would be most extreme.

Borthwick and Parker (1939) reported that the critical day length varies among different varieties of the cultivated soybean (Glycine soja); Borthwick (1961) noted that this variation parallels differences in the summer lay length at the lati- 
tudes to which different varieties are best adapted and are customarily grown. This situation is, of course, probably as much the result of conscious selection by man as of natural selection.

Katayama (1964) found a definite, though rather irregular, increase in critical day length with latitude of origin among strains from several species of wild and cultivated rice (Oryza).

Cumming (1963) found differences in photoperiodism among four strains of Chenopodium rubrum L. collected at latitudes between 34 and $63^{\circ} \mathrm{N}$. The races from $34.3^{\circ} \mathrm{N}$ (California) and $50.2^{\circ} \mathrm{N}$ (Saskatchewan) behaved at $15 \mathrm{C}$ as qualitative short-day plants with critical night lengths of about 10 and $7 \mathrm{hr}$ respectively. At $15 \mathrm{C}$ the race from $60.8^{\circ} \mathrm{N}$ (Yukon) acted as a quantitative short-day plant (flowering accelerated by but not dependent on short days) without a well-defined critical night length, while the race from $62.8^{\circ} \mathrm{N}$ (also Yukon) was almost day-neutral. The effects of photoperiod were considerably different when tested at $30 \mathrm{C}$.

We have examined the reproductive photoperiodism of strains of the cocllebur Xanthium strumarium L. obtained from wild populations at various localities in North America. Despite the extensive use of one or a few strains (all apparently derived from the vicinity of Chicago, lat. $42^{\circ} \mathrm{N}$ ) of this amnual plant in physiological studies of photoperiodism, few reports on the photoperiodic behavior of wild populations of it appear to exist. It is generally stated that $X$. strumarium is a shortday plant with a critical night length of $8.3-8.5 \mathrm{hr}$. Naylor (1952) discussed the flowering response of Xanthium in relation to latitude in terms that implied that the eritical night length does not vary from this value at different; latitudes; he stated that at the latitude of Miami $\left(26^{\circ} \mathrm{N}\right)$, where the night length is never less than $8.5 \mathrm{hr}$, cocklebur flowers whenever "physiologically ripe."

However, long ago Shull (1915) reported that different races of Xanthizm occurring near Lawrence, Kan., flowered at markedly different dates in August, which implies that they possessed different critical night lengths. He found that plants grown in Kansas from seed collected in South Dakota flowered very precociously (early July), suggesting that they had a shorter critical night length than strains native to Kansas (Shull did not, of course, interpret this observation in terms of photoperiodism, since the phenomenon was unknown at the time). More recently Carpenter and Lincoln (1959) reported that a strain of Xanthium collected in Los Angeles (lat. $34^{\circ} \mathrm{N}$ ) had a critical night length between 11 and $12 \mathrm{hr}$, which they felt was probably an adaptation to the southern latitude, compared with strains having a critical night length of $8.5 \mathrm{hr}$.

Lang (1947) reported a strain of $X$. strumarium that exhibited a quantitative response, as opposed to the qualitative photoperiodic response usual in
Xanthium. Lona (1946) found a day-neutral response in the distinct species $X$. spinosum.

The data to be presented here show a striking variation of critical night length with latitude in wild populations of $X$. strumarium, and give additional evidence for the existence of a quantitative short-day response in some strains.

Methons-Plant material-Plants were grown from seed collected out of doors in various localities as indicated in the tables. In keeping with the typically weedy character of $X$. strumarium most of the collections were from roadsides, cultivated fields, or waste land. Exceptions are lots 26, 27, and 34 which were from sandy lake shores and may represent "natural" populations (Löve and Dansereau, 1959).

We follow Löve and Dansercau (1959) in regarding all races of Xanthium (except $X$. spinosum which was not examined in the present work) as within the species $X$. strumarium $\mathrm{L}$. In the tables we give the morphological affinities of each strain, according to the usage of Löve and Dansereau (1959). As they stated, morphology intermediate between the named types is common and the classification is, therefore, rather arbitrary.

Herbarium specimens of representative mature fruiting plants of each strain raised and used in our experiments have been placed in the University of Michigan Herbarium. The labels of these specimens bear records of the original collectors of the seed and the exact localities of collection, and they also carry the strain numbers used in this paper.

Raising of plants-Burs were planted in glasscovered pots of sand, and soaked thoroughly with water containing 700 ppm Panodrench (Panogen Co., Ringwood, Ill.) to reduce damping off, then placed in the greenhouse under continuous supplementary illumination by photoflood incandesccnt lamps. After germination (1-2 weeks) seedlings were transplanted to individual pots containing a mixture of $2 / 3$ sterilized soil and $1 / 3$ sand and maintained in the greenhouse under continuous supplementary illumination (photoflood lamps or mercury are lamps) until they were used in photoperiod experiments or planted into outdoor plots. For the controlled environment chamber experiments the plants were transplanted to 6-inch plastic pots.

In general, photoperiod experiments were begun at an age of about 6 weeks, when the plants were about 10 inches tall. A number of tests with particular strains at different ages demonstrated that the characteristics of the photoperiodic response are not strongly infuenced by age of the plant, as found previously by Long (1939).

Fixerl night-length experiments - These were conducted June through August in a greenhouse and darkroom in which the temperature was not controlled. Maximum day temperature was usually 30-35 $\mathrm{C}$ and darkroom temperature was approximately $20 \mathrm{C}$. Plants were brought out of the darkroom between 7-9 $\Lambda \mathrm{M}$ and placed on the greenhouse 
benches under supplementary illumination. (Two 40-w "cool white" fluorescent and two 200-w incandescent lamps about $1 \mathrm{~m}$ above the tops of the plants.) Groups of plants were moved into the darkroom at various times during the evening on a schedule that provided the night-length treatments indicated in Fig. 1, 4. This schedule was maintained every day. The number of days of treatment after which a macroscopically visible terminal flower bud (1-2 $\mathrm{mm}$ in diameter) first appeared, and after which the first male flower opened, was determined.

Varying night-length experiments-These experiments were conducted in controlled environment chambers. Day temperature was $30 \mathrm{C}$, night temperature $18.5 \mathrm{C}$. Illuminato.n consisted of 228 foot VHO fluorescent lamps and $6 \quad 100-\mathrm{w}$ or 4 $150-w$ incandescent lamps, and was at least 2000 $\mathrm{ft}-\mathrm{c}$ at the level of the tops of the plants, the tops being about $0.5 \mathrm{~m}$ below the lamps. The timing clocks were set so that intensity was varied stepwise at the beginning of the photoperiod by turning on first the incandescent lamps, then $45 \mathrm{~min}$ later one-half of the fluorescent lamps (every other lamp across the light panel), and after $45 \mathrm{~min}$ more the remainder of the fluorescent lamps. Likewise at the end of the photoperiod one-half of the fluorescent lamps were extinguished first, then after $45 \mathrm{~min}$ the remainder of the fluorescent lamps, and $45 \mathrm{~min}$ later the incandescent lamps. The night length (period of total darkness) was thus set by the timing of the incandescent lamps. The day-night temperature transition was set to coincide with the first set of fluorescent lamps to be lighted and the last set of fluorescent lamps to be extinguished.

A group of 5-10 uninduced plants of a given lot was placed in a chamber on a night length that was known or suspected to be less than the critical length for that lot. The night length (including timing of all lights and day-night temperature transition) was increased by 15 min every i) days thereafter. The date and night length on which macroscopically visible (diameter $1-2 \mathrm{~mm}$ ) flower buds first appeared was determined for each plant. We call this night length the manifest night length. At this time five uninduced plants of the same lot, from a "control" group maintained under continuous light in the greenhouse as described above, were brought into a chamber under a night length at least $1.5 \mathrm{hr}$ longer than the manifest night length (i.e., they were given a fully inductive night length). The number of days before appearance of a macroscopically visible flower bud (referred to as the manifest interval) was determined for each plant. The determination of the manifest night length was considered satisfactory if the number of days that elapsed before appearance of flower buds in the varying night-length experiment was more than twice the manifest interval, and only if control plants under continuous illumination did not produce flower buds. That this cri- terion is meaningful is indicated by the observation that the manifest night length of various strains determined in this way was found to be about the same when plants of a given lot were tested beginning at different initial night lengths.

Natural-day experiments-Response of cocklebur plants to natural photoperiod was tested in experiments conducted in the greenhouse and in outdoor field plots.

In the greenhouse experiment, begun July 31, 1962 at the University Botanical Gardens, Ann Arbor, Michigan, lat. $42.3^{\circ} \mathrm{N}$, uninduced plants were placed next to a large north-facing window at the end of the greenhouse. The roof of the greenhouse was whitewashed according to usual summer greenhouse practice but the north window was not whitewashed, affording direct exposure to part of the morning and evening sky. Temperature was maintained at or above $18 \mathrm{C}$.

Outdoor plantings were made in cultivated fields at the same locality in mid-July, 1963, from plants started in the greenhouse in the manner described previously.

The date of first appearance of macroscopically visible flower buds was determined for each plant in both of these experiments, and the sunset to sunrise night length on this date at lat. $42.3^{\circ} \mathrm{N}$ was found from astronomical tables. The expected clate of appearance of flower buds at the latitude of origin of each strain was found by ascertaining the date on which the natural night at that latitude would have the same length as that at which flower buds appeared under natural day in Ann Arbor.

RESULTS-Fixed night-length experiments-Results of exploratory tests of six strains of Xanthium from different latitudes, performed by subjecting groups of plants to photoperiods of fixed duration, are given in Fig. 1. The experiments were performed three times with each strain with essentially the same results. The eritical night length, i.e., the minimum night length under which macroscopically visible flower buds were produced, varied from 8.0-8.5 hr for the northern strains to $10.5 \mathrm{hr}$ for the southern strains.

To test more extensively the relation between critical night length and latitude in Xanthium, a series of experiments involving varying night lengths was performed with a larger number of strains.

Varying night-length experiments-We denote by "manifest night length" the night length under which macroscopically visible flower buds first appear when plants are subjected to a night length that is increased gradually, during the experiment, at or about the same rate as the night length increases out of doors in late summer. The manifest night length will be slightly longer than the critical night length; we discuss below the relation between them more exactly. Varying night-length experiments were performed, primarily because with them it was possible to obtain information 


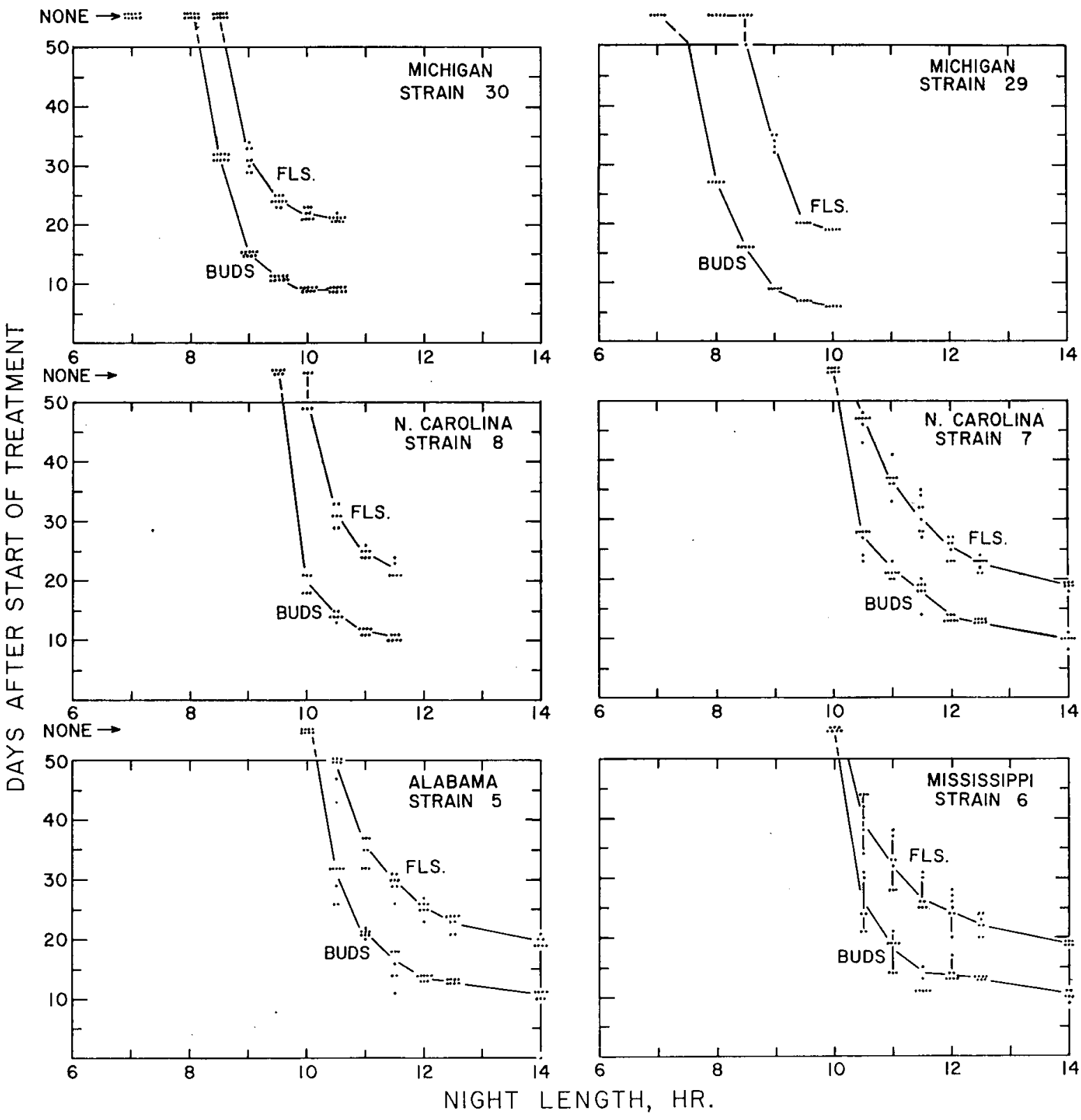

Fig. 1. Flowering responses of six strains of Xanlhium slrumarium under fixed night-length regimes. Fach point indicates for a particular plant the number of days after start of treatment at which a macroscopically visible flower bud appeared (lower curve) or the first male flower opened (upper curve). Points above the top of each graph show treatments under which a response was not obtained within 50 days.

about differences in critical night lengths much more economically than in fixed night-length experiments, and thus it was feasible to examine a much larger number of strains simultaneously. Also, the results of varying night-length experiments can more readily be applied to the performance of plants in nature. Results of these determinations on all the strains examined are recorded in Tables 1,2, and representative figures are plotted in Fig. 2.

In the varying night-length experiments, the flower buds, once they become macroscopically visible (1-2 $\mathrm{mm}$ in diam), grow so rapidly that one can be certain of detecting the time of their appearance to within 1-2 days. Furthermore, with almost all strains the buds appeared within an interval of 1-4 days on all plants of a lot. Thus in most experiments the manifest night length was determined to within $0.25 \mathrm{hr}$, which was the interval between successive clock settings in the controlled environment equipment. Instances in which different plants of one lot devcloped visi- 
TARLE 1. Photoperiodic characteristics of Xanthium sirumarium strains detcrmined under controlled conditions by the varying night length method

\begin{tabular}{|c|c|c|c|c|c|c|}
\hline Strain & Complex & Origin & $\begin{array}{l}\text { Lat. } \\
{ }^{\circ} \mathrm{N}\end{array}$ & $\begin{array}{c}\text { Manifest } \\
\text { night length } \\
\text { hr }\end{array}$ & $\begin{array}{l}\text { Manifest } \\
\text { interval } \\
\text { days }\end{array}$ & $\begin{array}{l}\text { Apparent } \\
\text { critical night } \\
\text { length hr }\end{array}$ \\
\hline 1 & pe. (ch.) & Querétaro, Mexico & 20.4 & $10.0-10.25$ & 9 & 9.75 \\
\hline 50 & ec. & Oahu Island, Hawaii & 21.3 & $10.0->12.00$ & $-\mathrm{b}$ & $-b$ \\
\hline 2 & ca. (it.) & Houston, Texas & 29.8 & $10.5-10.75$ & 10 & 10.25 \\
\hline 3 & it. & Austin, Texas & 30.3 & 11.0 & $9-10$ & 10.5 \\
\hline 4 & it. & Llano, Texas & 30.8 & $10.25-10.5$ & $8-11$ & $10.0-10.25$ \\
\hline 53 & ch. & Bacon Co., Gia. & 31.5 & 10.25 & $10-11$ & 10.0 \\
\hline 5 & ch. & Montgomery, Ala. & 32.4 & 10.75 & 11 & 10.0 \\
\hline 54 & it. & Fort Worth, Texas & 32.7 & 9.5 & 8 & 9.25 \\
\hline 6 & ch. & Bolivar Co., Miss. & 33.8 & $10.5-10.75$ & $9-11$ & $10.0-10.25$ \\
\hline 55 & ch. & Athens, Gr. & 34.0 & 10.25 & $7-9$ & 10.0 \\
\hline 56 & ch. & Tishomingo Co. & 31.6 & $9.5-9.75$ & $9-10$ & $9.25-9.5$ \\
\hline 7 & ch. & Mecklenburg Co., N. C. & 35.1 & & & $10.25^{\mathrm{c}}$ \\
\hline 8 & ch. & Cleveland Co., N. C. & 35.3 & $10.0-10.25$ & 9 & 9.75 \\
\hline 57 & ch. & Nashville, Tenn. & 36.1 & 9.75 & 9 & 9.5 \\
\hline 58 & it. & Nashville, Tenn. & 36.1 & 9.0 & $7-9$ & 8.75 \\
\hline 59 & ch. & Cumberland Co., Ky. & 36.8 & $9.75-10.0$ & $7-8$ & 9.5 \\
\hline 60 & ch. & Union Co., Ill. & 37.3 & $9.25-9.75$ & 9 & $9.0-9.25$ \\
\hline 61 & st. & MoLean Co., Ky. & 37.5 & $9.5-9.75$ & $7-8$ & $9.25-9.5$ \\
\hline 62 & eh. & Perry Co., IIo. & 37.6 & 9.5 & $7-9$ & 9.25 \\
\hline 9 & pe. (cat.) & Contra Costa Co., Calil'. & 37.7 & 9.25 & $8-12$ & 8.75 \\
\hline 10 & pe. & Napa, Calif. & 38.3 & $9.0-9.25$ & $7-11$ & 8.75 \\
\hline 63 & ah. & Lewis Co., Ky. & 38.6 & 9.5 & $7-8$ & 9.25 \\
\hline 11 & ch. & Callaway Co., Mo. & 38.6 & $9.25-9.5$ & $7-8$ & 9.0 \\
\hline 12 & ch. & Marion Co., Ill. & 38.6 & 9.0 & $6-8$ & 8.75 \\
\hline 13 & it. (or.) & Marion Co., Ill. & 38.6 & 8.75 & 10 & 8.5 \\
\hline 14 & ch. & Marion Co., Ill. & 38.6 & $9.25-9.5$ & $8-9$ & $8.75-9.0$ \\
\hline 15 & ch. & Daviess Co., Ind. & 38.7 & 9.25 & $6-8$ & 8.75 \\
\hline 16 & ch. & Knox Co., Ind. & 38.7 & 8.75 & 9 & 8.5 \\
\hline 64 & (rh. & Mason Co., W. Val. & 38.7 & 9.0 & $7-9$ & 8.75 \\
\hline 17 & it. & St. Louis, Mo. & 38.7 & 8.5 & 9 & 8.25 \\
\hline 18 & (h). & Cincinnati, Ohio & 39.2 & 9.5 & 9 & $9.0-9.25$ \\
\hline 19 & it. & Greene Co., Ohio & 39.8 & $8.75-9.0$ & 10 & 8.5 \\
\hline 20 & pe. & Greene Co., Ohio & 39.8 & 8.75 & 9 & 8.5 \\
\hline 21 & ch. & Greene Co., Ohio & 39.8 & $8.75-9.0$ & 8 & $8.5-8.75$ \\
\hline 22 & it. & Chicago, Ill. & 41.6 & 8.5 & $9-10$ & 8.25 \\
\hline 23 & it. & Chicago, Ill. & 41.6 & 8.5 & $7-9$ & 8.25 \\
\hline 24 & it. & Chicago, Ill. & 41.6 & 8.5 & $8-10$ & 8.25 \\
\hline 25 & pe. & Chicago, Ill. & 41.6 & 8.5 & $10-11$ & 8.25 \\
\hline 26 & it. & Wayne Co., Mieh. & 42.1 & $8.5-8.75$ & 10 & 8.25 \\
\hline 27 & it. & Wayne Co., Mich. & 42.1 & 8.75 & 10 & $8.25-8.5$ \\
\hline 28 & ch. & Washtenaw Co., Mich. & 42.2 & 8.25 & 7 & 8.0 \\
\hline 29 & pe. & Washtenaw Co., Mich & 42.2 & 8.25 & 一 & 一 \\
\hline 30 & pe. (ii.) & Washtenaw Co., Mieh & 42.3 & 8.25 & 7 & 8.0 \\
\hline 31 & ov. & Montgomery Co., X. Y' & 42.8 & 8.25 & 7 & 8.0 \\
\hline 65 & pe. & Malheur Co., Ore. & 44.1 & $8.0-8.25$ & 7 & $7.75-8.0$ \\
\hline 32 & pe. & Redwood Co., Minn. & 44.2 & $8.0-8.25$ & $6-8$ & 7.75 \\
\hline 33 & pe. (it.) & Crawford Co., Mich. & 44.8 & 8.75 & 9 & 8.5 \\
\hline $3+4$ & pe. & Emmot Co., Mich. & 45.4 & $8.0-8.25$ & $6-8$ & 7.75 \\
\hline 35 & ec. (po.) & Montreal, Quebec & 45.5 & 8.0 & 9 & 7.5 \\
\hline
\end{tabular}

"Morphological "complex" following usage of Jöve and Dansereau (1959): ca., cavanillesii; ch., chinense; cc., echinatum; it., italicu $n$; or, orientale; ov., oviforme; pe, pensylvanicum; st., strumariun. Notations in parentheses indicate morphology intermediate between named types.

b See text and Fig. 4.

- Determined from fixed night-length experiment (Fig. 1).

ble flower buds under different photoperiods are indicated as a range in the tables.

Most of the strains were tested at least twice, usually at different ages. The manifest night lengths found for a given strain in different experiments sometimes differed by $0.25 \mathrm{hr}$. These differences were not clearly correlated with age of the plant, within the limits of about 60-140 days. The 


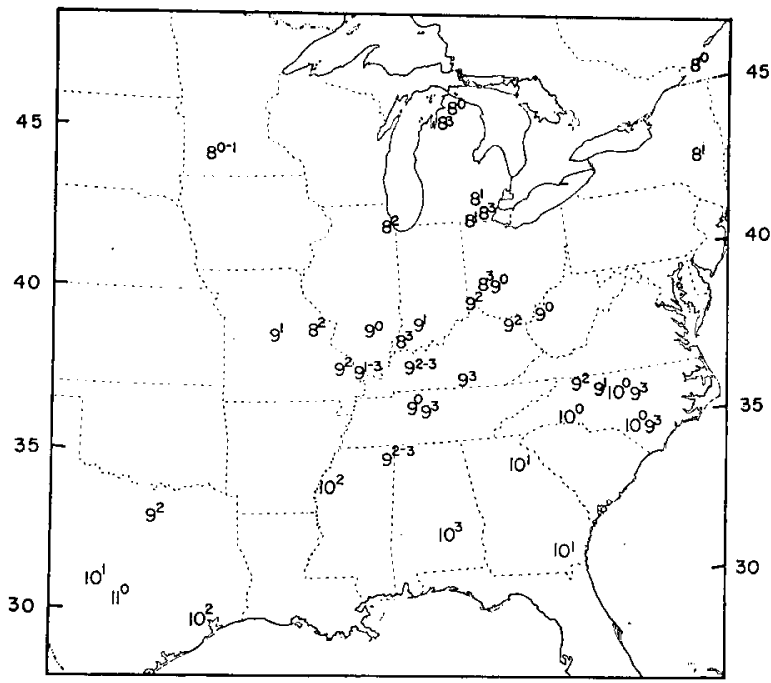

Fig. 2. Geographic distribution of manifest night length in strains of Xanthium strumarium from eastern North America. For each collection the manifest night length is indicated in hours and, by superseript, quarters of an hour: $9^{3}$ indicates $9.75 \mathrm{hr}$ manifest night length, $9^{\circ}$ indicates 9.0 hr, $9^{\mathrm{I}-2}$ indicates $9.25-9.5 \mathrm{hr}$, etc.

figures given in Table 1 pertain to the test in which the response occurred at an age nearest to 70 days.

It is clear from Table 1 and Fig. 2 that there is a strong, although not absolute, correlation between manifest night length and latitude of origin. There appears to be a tendency for the manifest interval (see Methods, and below) to be somewhat longer for southern strains, but the differences in this respect are not nearly so striking as with the manifest night length.

The observed differences in photoperiodic behavior do not appear to be correlated with morphological characteristies, for short manifest night lengths were found for northern strains and long manifest night lengths for southern strains belonging to the same morphological "complex."

The critical night length was estimated from the varying night-length experiments by taking into account the manifest interval. If it requires $x$ days (the manifest interval) to obtain visible flower buds under a fully inductive photoperiodic regime, then we know that the photoperiod which the plants were receiving $x$ days before buds appeared in the varying night-length experiment was an inductive photoperiod. Since the manifest interval was generally 7-10 days, whereas the night length was being increased by 15 min every five days, a night length 15-30 min shorter than the manifest night length must be a maximum value for the critical night length. The value is a maximum because in the neighborhood of the critical night length the photoperiodic effectiveness is less than that of longer night lengths (i.e., we are on the strongly sloping part of the curves in Fig. 1).

From the records the maximum value of the
TABLE 2. Strains of Xanthium strumarium from North Carolina

\begin{tabular}{|c|c|c|c|}
\hline Strain & County & $\begin{array}{l}\text { Lat. } \\
{ }^{\circ} \mathrm{N}\end{array}$ & $\begin{array}{c}\text { Manifest } \\
\text { night length } \\
\mathrm{hr}\end{array}$ \\
\hline 361 & Bladen & 34.7 & $9.75-10.0$ \\
\hline 371 & Biaden & 34.7 & $9.75-10.0$ \\
\hline 381 & Bladen & 34.8 & 10.0 \\
\hline 39 & Cumberland & 35.0 & $9.75-10.0$ \\
\hline 40 & Cumberland & 35.0 & 9.75 \\
\hline 410 & Cumberland & 35.1 & $9.75-10.0$ \\
\hline $42 \mathrm{I}$ & Harnett & 35.3 & $9.75-10.0$ \\
\hline $43 \mathrm{I}-\mathrm{I}-\mathrm{s}$ & Wake & 35.9 & 9.75 \\
\hline 44( & Orange & 35.9 & $10.0-10.25$ \\
\hline 450 & Orange & 35.9 & 9.75 \\
\hline $46 C$ & Orange & 35.9 & $9.75-10.25$ \\
\hline 47 & Orange & 35.9 & $9.75-10.0$ \\
\hline $48 \quad$ & Guilford & 36.1 & 9.5 \\
\hline 495 & Surry & 36.5 & 9.75 \\
\hline
\end{tabular}

"All these strains belong to complex chinense, although the sizes of the burs varied considerably among the different collections.

critical night length was estimated in this way for each strain for which the manifest interval was determined, and the results are listed in Table 1. These values agree fairly closely with the critical night lengths found for the same strains in the fixed night-length experiments (Fig. 1).

To study photoperiodic variation within a more limited geographic region, the manifest night length was determined simultaneously for 14 different collections from adjacent counties in North Carolina (Table 2). The different lots did not all behave identically, a range of $0.75 \mathrm{hr}$ in manifest night length being encountered among the plants tested. But the variation in photoperiodic response was much less than that observed over the wider range of latitudes represented in Table 1.

With a few strains, as recorded in Table 3 , some or all of the control plants eventually produced fower buds under continuous illumination in the greenhouse. In all these cases (except strain 2) this took place tardily, and the buds were slow to develop further, although some plants finally did flower and produce a few fruits.

Flowering under continuous illumination was associated with the appearance of aberrant leaf forms having small, irregularly lanceolate or ocensionally lobed blades (Fig'. 3). Similar leaf blades were also formed when strains 29 and 30 were maintained continuously on a photoperiod just at the eritical, in the experiment of Fig. 1.

These abnormalities and the slow reproductive development indicate that the flowering of some strains or individuals under continuous illumination involves a weak and marginal flowering stimulus compared to that which can be produced by inductive night lengths. Since these strains flowered and fruited rapidly under an inductive photo- 
TABLE 3. Formation of flower buds under continuous lighl

\begin{tabular}{|c|c|c|c|c|}
\hline Struin & Origin & $\begin{array}{l}\text { Age when } \\
\text { flower } \\
\text { buds } \\
\text { appeared } \\
\text { days }\end{array}$ & $\begin{array}{l}\text { No. of plants } \\
\text { producing } \\
\text { flower } \\
\text { buds }\end{array}$ & $\begin{array}{c}\text { Total no. } \\
\text { of } \\
\text { plants }\end{array}$ \\
\hline 2 & Texas & $50-59$ & 9 & 29) \\
\hline 4 & Texas & $70-80$ & 3 & 29 \\
\hline 9 & Calif. & ca. 110 & 13 & 13 \\
\hline 10 & Calif. & ai. 100 & 20) & 20 \\
\hline 28 & Mich. & ca. 100 & 14 & 14 \\
\hline 35 & Que. & (a. 100 & 12 & 13 \\
\hline 41 & N. C. & cat. 45 & 2 & 8 \\
\hline 66 & Francea & $70-80$ & 15 & 15 \\
\hline
\end{tabular}

a Châteauneuf-du-Pape (Vaucluse), France, Lat. $44.0^{\circ} \mathrm{N}$; complex oviforme. Plants of this strain showed a manifest interval of 12 days under 12-hour night. Manifest night length of this strain hats not yet been estahlished.

period, they evidently possess a quantitative rather than qualitative photoperiodic response.

Collections 2, 4 and 41 were peculiar in that only some of the plants flowered under noninductive photoperiod. Those that remained vegetative were subsequently divided into control and experi-

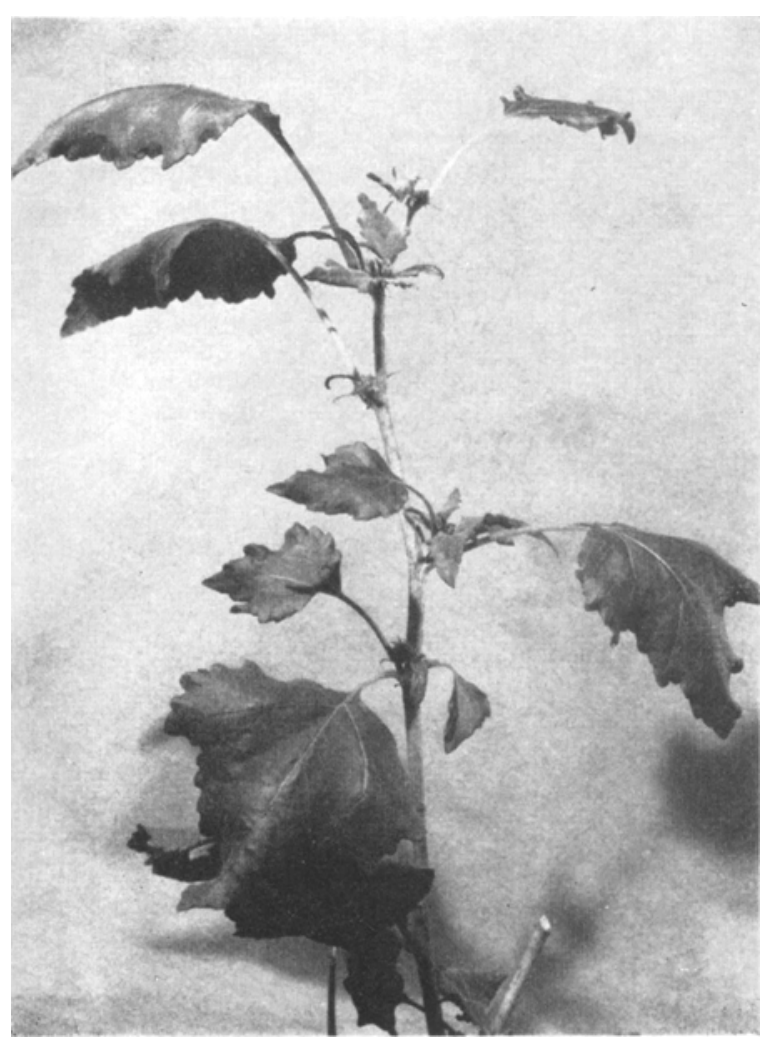

Fig. 3. A plant of strain 35 (Montreal, Quebec) which flowered under continuous illumination in the greenhouse. Note the abnormally shaped leaves surrounding the terminal and lateral inflorescences and the weak development of the inflorescences. mental groups and the latter were subjected to varying night-length treatment in order to ascertain their manifest night length (results recorded in Table 1). During the period of the experiment the respective control groups remained vegetative.

In a separate experiment seedlings of strains 1,2 and 3 were subjected to an 8-hr day-16-hr night regime immediately after germination. All the plants produced flower buds within about 12 days. Thus it appears that a certain proportion of the plants in each of these seed lots possessed a cuantitative photoperiodic; response that permitted eventual flowering under continuous illumination, whereas the remainder showed a qualitative response so far as can be judged from the observations. (This experiment was set up to test for the possibility of a long-short-day response in thesc southern strains and it obviously yielded negative results for this type of response.)

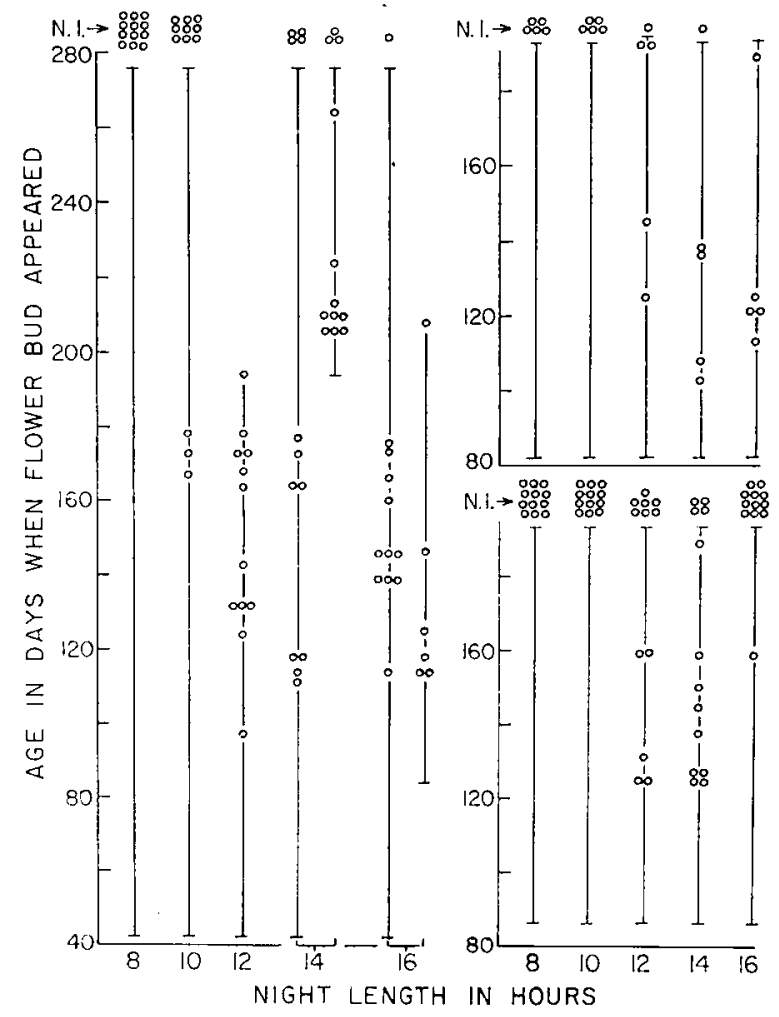

Fig. 4. Response of Xanthium strumarium strains from Oahu Island, Hawaii, to fixed night lengths. Ordinate shows the age of the plants, in days from sowing, at which flower buds appeared; vertical bars extending through the points show the duration of photoperiodic treatment, the plants having been under continuous illumination prior to the beginning of treatment. N. I. indicates plants that had not produced flower buds at the conclusion of the experiment. Left, Strain 50, Kolio Head Crater; upper right, Strain 51, Kaena Point; lower right, Strain 52, Waialua. Each treatment contained 12 plants, except with Strain 51 ( 5 plants) and in the 16-hr night treatment of Strain 50 that was begun at age 84 days ( 6 plants). Abscissa for Strain 51 is same as at lower right. 
TABLE 4. Flower bud formation under natural day al Ann Arbor, Mich. (Lat. 42.3 $3^{\circ}$ )

\begin{tabular}{|c|c|c|c|c|c|}
\hline Strain & Origin & Lat. ${ }^{\circ} \mathrm{N}$ & $\begin{array}{l}\text { Date buds } \\
\text { appeared }\end{array}$ & $\begin{array}{c}\text { Night length } \\
\mathrm{hr}\end{array}$ & $\begin{array}{l}\text { Expected } \\
\text { date at lat. } \\
\text { of origin }\end{array}$ \\
\hline \multicolumn{6}{|c|}{ Field tests } \\
\hline 2 & Texas & 29.8 & $9 / 22-10 / 4$ & $11.75-12.4$ & $9 / 10-9 / 19^{\mathrm{b}}$ \\
\hline 3 & Texas & 30.3 & $9 / 19-10 / 11$ & $11.6-12.7$ & $9 / 14^{\circ}$ \\
\hline 4 & Texas & 30.8 & $10 / 11$ & 12.7 & $9 / 11^{\mathrm{b}}$ \\
\hline 6 & Miss. & 33.8 & $9 / 18$ & 11.6 & $9 / 3^{d}$ \\
\hline 9 & Calif. & 37.7 & $8 / 18^{a}$ & 10.2 & $(8 / 10)$ \\
\hline 10 & Calif. & 38.3 & $8 / 7^{a}$ & 9.75 & $(7 / 29)$ \\
\hline 12 & Ill. & 38.6 & $8 / 14-8 / 18$ & $10.1-10.2$ & $8 / 10-8 / 14$ \\
\hline 13 & Ill. & 38.6 & $8 / 11-8 / 14$ & $9.9-10.1$ & $8 / 7-8 / 11$ \\
\hline 17 & Mo. & 38.7 & $8 / 14$ & 10.1 & $8 / 10$ \\
\hline 18 & Ohio & 39.2 & $8 / 23$ & 10.4 & $8 / 18$ \\
\hline 22 & Ill. & 41.6 & $8 / 7-8 / 11$ & $9.75-9.9$ & $8 / 7-8 / 11$ \\
\hline 24 & Ill. & 41.8 & $8 / 7$ & 9.75 & $8 / 7$ \\
\hline 25 & Ill. & 41.8 & $8 / 7-8 / 11$ & $9.75-9.9$ & $8 / 7-8 / 11$ \\
\hline 27 & Mich. & 42.1 & $8 / 15-8 / 17$ & $10.1-10.2$ & $8 / 15-8 / 17$ \\
\hline 30 & Mich. & 42.3 & $8 / 7$ & 9.75 & $8 / 7$ \\
\hline 34 & Mich. & 45.4 & $8 / 4$ & 9.6 & $8 / 10$ \\
\hline 35 & Que. & 45.5 & $8 / 1-8 / 4$ & 9.5 & $8 / 7$ \\
\hline \multicolumn{6}{|c|}{ Greenhouse tests } \\
\hline 5 & Ala. & 32.4 & $9 / 12$ & 11.3 & $9 / 5$ \\
\hline 6 & Miss. & 33.8 & $9 / 10-9 / 12$ & $11.2-11.3$ & $9 / 3$ \\
\hline 7 & N. C. & 35.1 & $9 / 7$ & 11.1 & $9 / 2$ \\
\hline 8 & N. C. & 35.3 & $9 / 5$ & 11.0 & $8 / 30$ \\
\hline 29 & Mich. & 42.2 & $8 / 7$ & 9.75 & $8 / 7$ \\
\hline 30 & Mich. & 42.3 & $8 / 7$ & 9.75 & $8 / 7$ \\
\hline
\end{tabular}

"In the ficld flower buds appeared not more than 10 days before buds appeared on control plants under continuous illumination in greenhouse. The natural night length at which buds appeared was, therefore, probably not fully characteristic of the photoperiodic response.

b Found from the manifest night length (Table 2 ) and an allowance of $1.0 \mathrm{hr}$ for effect of twilight.

' For 11.6-hr night length.

d Found from greenhouse results.

e Determined from astronomical tables, as described in Methods, except as noted in footnotes b-d.

Hawaiian strains-A flowering response departing even more from what is regarded as typical for Xanthium was encountered in strains obtained from Hawaii. Plants of one of these (No. 50) were tested first in a varying night-length experiment and cxhibited erratic behavior, different individuals developing flower buds at widely different night lengths from $10 \mathrm{hr}$ upwards, some individuals finally flowering only after many weeks under 16hr night. Plants of three collections from Hawaii were then subjected in the greenhouse and darkroom to fixed night lengths of $8,10,12,14$ and 16 hr. The results are shown in Fig. 4. In all three cases substantial induction occurred only under night lengths of $12 \mathrm{hr}$ and longer, although 3 out of 12 plants of No. 50 eventually developed buds under 10-hr night. No buds were ever produced under 8-hr night or continuous illumination. But the response under inductve photoperiods was extreme y tardy and errat c, being spread out ove" months among the different individuals of each lot. Moreover, in most groups of plants under induc- tive photoperiod some individuals remained vegetative even after prolonged photoperiod treatment (6 months in the case of No. 50), when the experiments were terminated because the plants had become too large to be moved between greenhouse and darkroom.

This peculiar behavior may be due in part to a ripeness-to-flower effect, since no plants became induced before about 100 days of age regardless of when short-day treatment was begun, whereas plants brought into short day at age 194 days became induced relatively quickly (but not all such plants became induced; see Fig. 4). The possibility of a long-short-day response being involved here has perhaps not been ruled out since in all cases the plants were brought from continuous light into short day (there might be a requirement for pretreatment with long days that is not satisfied by continuous light). In any event, the results with Hawaiian plants seem most unusual and their response deserves further study.

Natural-day experiments - These were performed 
in order to better relate the results of the controlled environment chamber experiments to performance in nature. One test was conducted under natural day in the greenhouse, where temperature was maintained at favorable values, and a second, larger test was run during the summer in a field plot at Ann Arbor, so that both photoperiod and mean temperature decreased in the course of the experiment. The results are given in Table 4.

These tests agreed with the results of controlled photoperiod experiments in showing that Xanthium strains from southerly latitudes possess longer critical night lengths; the farther south the locality of origin, the later the plants produced flower buds under naturally varying photoperiod. The sunsetto-sumrise night length at which flower buds first appeared was in most cases about $1 \mathrm{hr}$ longer under natural photoperiod than in the varying nightlength experiments performed in the controlled environment chambers with artificial illumination. This indicates that morning and evening twilight adds in all about $1 \mathrm{hr}$ to the effective length of the photoperiod for Xanthium and is in agreement with the conclusion that has been reached by earlier workers (Greulach, 1942; Takimoto and Ikeda, 1961).

Flower bud formation by the Mississippi and Texas strains was delayed outdoors in Ann Arbor in comparison with the performance of these strains in the greenhouse and controlled environment experiments. This was due, undoubtedly, to the cooler temperature prevailing outdoors in September.

In the field plot development of flower buds after their appearance and the development of the fruits after anthesis was noticeably retarded in all strains that became induced after the middle of August. As illustrated in Fig. 1, under favorable temperature and photoperiod anthesis occurs about 10 days after first appearance of flower buds in all strains tested. In the field plot anthesis had not taken place in strains 9,12 and 18 on September 14, which was at least 27 days after the first appearance of buds in the case of the first two strains and 22 days in the case of the last one. Whereas by September 14 all strains that had shown flower buds prior to August 11 had produced full-grown fruits, strains 17 and 13 were just in anthesis, a full month after their buds had first appeared. In the case of the Mississippi and Texas strains (2, 3, 4, 6 ), which did not produce visible flower buds in the field plot until after the middle of September, the buds did not even reach anthesis by October 14 , on which date they were killed by frost. Thus the plants of these strains failed to produce any seeds at all. The previously mentioned strains from intermediate latitudes produced some mature fruits, although many of their fruits appeared to be jmmature at the time the plants were killed by frost. That they were able to reproduce to any extent may be attributed to the late onset of killing frosts that particular season; it is clear that these strains from intermediate latitudes would fail to produce any seeds at Ann Arbor if a killing frost occurred in mid-September, as not infrequently happens at this latitude.

Discussion-The following observations indicate that the differences in critical night length found between different strains are genetically determined: (1) The critical night length or manifest night length is consistent in successive generations of plants of a given strain. Strains 5, 6, 8, 28 , and 30 have been tested through three generations derived from the original seed. (2) When plants of different strains are crossed, the hybrids have a critical night length intermediate between the parents, and segregation for critical night length is observed in the $F_{2}$ generation (these experiments will be the subject of a subsequent report).

It is apparent from the results of the field tests that the differences in eritical night length between Xanthium strains from different latitudes are of great importance in the reproduction and hence survival of the species in nature. Several environmental factors that vary with latitude may be expected to influence the reproductive effectiveness of the plant in relation to its critical night length and thereby may be anticipated to exert selective pressure tending to bring about evolution, at different latitudes, of races having different critical night lengths.

First, of course, is the fact that summer night length is shorter at more northerly latitudes. In order to flower on a given date, a northern plant must have a shorter critical night length than a southern plant. At a given latitude, the shorter the critical night length, the earlier after the summer solstice a short-day plant will flower. The obvious factor that selects in favor of shorter critical night length and thus earlier flowering is autumn temperature. The results of our field tests on Xanthium call attention to the point that the selective pressure arises not only from the terminal effect of freezing temperature, but also perhaps as significantly from the strong retardation of reproductive development in Xanthium that is caused by even the modest reduction of temperature in late August and early September. Northern strains are generally so constituted as to undergo induction early in August. If induction at that time is delayed by even 2 weeks the rate of subsequent development may be slowed so much by cooler autumn temperatures that whether or not mature fruit are produced would hinge tenuously on the yearly happenstances of early frosts in September or October.

However, other factors tend to select against a short critical night length, especially at southern latitudes. As noted previously, if Xanthium seed are germinated under an inductive photoperiodic regime, a visible flower bud appears within about two weeks after germination, at which time the seedling possesses two pairs of foliage leaves; not 
more than about three or four fruits (at most twice that many seed) are produced by this small plant. From this inconsequential seed production the amount of seed per plant increases with the age and size of the plant, at the time vegetative growth is terminated by floral induction, up to more than 1000 fruits per plant. Due to the variation of summer night length with latitude, the farther south the locality the longer must the critical night length be in order to avoid precocious flowering and inadequate seed production.

Selection against a short critical night length in a short-day plant should occur not only in relation to the proper timing of flowering following the period of vegetative development, but also with regard to the photoperiod that prevails at the beginning of the growing season. Unless the critical night length is longer than this initial photoperiod, induction will occur soon after germination and seed production will be minimal. The occurrence at southern latitudes of temperatures favorable for germination and induction earlier in the year, when nights are longer, will tend to select for a longer critical night length in southern races. This effect will tend, moreover, to result in the critical night length varying more strongly with latitude than does the length of the midsummer (e.g., August 1) natural night.

In fact, the critical night length was found to be more than $2 \mathrm{hr}$ greater in strains from latitudes around $30^{\circ} \mathrm{N}$ as compared with those from $45^{\circ} \mathrm{N}$, although the August 1 natural night length differs by little more than $1 \mathrm{hr}$ between these latitudes. As shown in Table 3 , the effect of this divergence is to make the expected date of flower bud appearance in southern strains at their latitudes of origin fall about a month later (i.e., early September) than that of northern strains at their native latitudes. Our observations and those of persons who have sent us seed support the view that in the southcrn United States $X$ anthium does, in general, flower about a month later than in the north (which is of course the opposite of what would be expected purely on the basis of the latitudinal difference in day length, as discussed, for example, by Naylor, 1952). In terms of behavior in the spring, this difference pushes back the first date that would appear to permit vegetative growth without floral induction from early May at the northern latitudes to early April at the southern latitudes. Further flexibility is no doubt afforded by the fact that low night temperature (as prevails in early spring) increases the critical night length (Long, 1939).

In any event it seems plain that the critical night length of northern races is as ill-adapted to the photoperiodic and climatic regime of southern latitudes as the behavior of southern races is to the regime that prevails in the north. In fact, typical northern races $\left(40^{\circ} \mathrm{N}\right)$ with a critical night length of about $8.25 \mathrm{hr}$ could hardly stand a chance of becoming established at a latitude of $30^{\circ} \mathrm{N}$ because the natural night length (even taking into account twilight) is never less than this value and hence the seedlings would suffer immediate induction whenever they germinated.

No clear correlation between occurrence of a quantitative photoperiodic response and latitude or other geographic factors is apparent as yet (Table 3), although plausible reasons can be suggested why such a response might be advantageous in mild climates. The occurrence of quantitative response may, however, explain instances of flowering of Xanthium in nature at unusual times of year.

The Hawaiian collections may possibly exemplify a response typical of tropical strains of this species. They exist in climates where germination and vegetative growth can occur at any time of year, and a weak and tardy photoperiodic response serves merely to ensure that each plant will eventually flower. For a weedy species in the tropics there may indeed be a real advantage in the erratic nature of the flowering response so that seed production for the potential colonization of new sites will be occurring through much of the year. There is, as pointed out by Hiesey and Milner (1965), a dearth of information relating the adaptive responses of tropical and temperate ecotypes of the same species, and this inadequacy applies to the present observations to the extent they have been carried thus far.

In conclusion, the photoperiodic response of Xanthium strumarium presents an interesting example of adaptation of a physiologically important character in relation to environmental variables, and it offers some attractive possibilities for the quantitative investigation of physiological evolution.

\section{LITERATURE CITED}

BonTuwick, H. A. 1961. light, flowering, and the production of seed, p. 37-45. In Seeds. U.S. Department of Agriculture, Government Printing Office, Washington, D. C.

—, AND M. W. PARker. 1939. Photoperiodic responses of several varieties of soybeans. Bot. Gaz. 101: 341-365.

Carpenter, B. H., and R. G. Iincoln. 1959. Requirements for floral initiation of Ios Angeles Xanthium. Science 129: 780-781.

Cummina, B. G. 1963. Evidence for a requirement for phytochrome- $\mathrm{P}_{\mathrm{fr}}$ in the floral initiation of Chenopodium rubrum. Can. J. Bot. 41: 901-926.

Greulach, V. A. 1942, The length of the photoperiodically effective twilight period. Ohio J. Sci. 42: 7172.

Hiesey, W. M., And H. W. Mruner. 1965. Physiology of ecological races and species. Ann. Rev. Plant Physiol. 16: 203-216.

Inatayama, T. C. 1964. Photoperiodism in the genus Oryza. II. Jap. J. Bot. 18: 349-383.

Lang, A. 1947. Beiträge zur Genetik des Photoperiodismus. II. Photoperiodismus und Autopolyploidie . Zeits. Naturforsch. 2b: 36-44. 
Lona, F. 1946. Sul comportamento fotoperiodico di alcune specie di Xanthium. Nuovo Giorn. Bot. Ital., N. S. 53: $635-656$.

Long, E. M. 1939. Photoperiodic induction as influenced by environmental factors. Bot. Gaz. 101: 168-188.

Löve, D., and P. Dansereau. 1959. Biosystematic studies on Xanthium: taxonomic appraisal and ecological status. Can. J. Bot. 37: 173-208.

McMrllan, C. 1960. Ecotypes and community function. Amer. Nat. 94: 245-255.
NAYLOR, A. W. 1952. The control of flowering. Sci. Amer. 186 (5): 49-56.

Shull, C. A. 1915. Physiological isolation of types in the genus Xanthium. Bot. Gaz. 59: 474-483.

TAkimoto, A., AND K. Ikeda. 1961. Effect of twilight on photoperiodic induction in some short-day plants. Plant and Cell Physiol. 2: 213-229.

VAARTAJA, O. 1962. Ecotypic variation in photoperi. odism of trees with special reference to Pinus resinosa and Thuja occidenlalis. Can. J. Bot. 40: 849 856 .

Amer. J. Bot. 53(8): \$16-820. 1966.

\title{
EFFECTS OF IONIZING RADIATION AND FIRE ON GAYLUSSACIA BACCATA AND VACCINIUM VACILLANS
}

\author{
R. D. Brayton and G. M. Woodwell \\ Department of Botany, Rutgers-The State University, New Brtunswick, N. J. \\ and \\ Biology Department, Brookhaven National Laboratory, Upton, N. Y.
}

\section{A B S T R A C T}

Fire and ionizing radiation have parallel effects on survival of natural populations of Gaylussacia baccata and Vaccinium vacillans. Vaccinium is substantially more resistant to both. The differences in survival are due to differences in regenerative capacity; buds of Vaccinium are more resistant to damage, occur at greater depths in the soil, and are better protected from both radiation and heat. This pattern of radiation and fire resistance lends further support to the general observation that in plants radiation resistance is related to ecological hardiness.

THE RESPONSES of plants to ionizing radiation have been shown to depend on a variety of environmental and intrinsic characteristies. The principal intrinsic characteristic appears to be the average size of the chromosome at interphase (Sparrow and Woodwell, 1962; Sparrow, 1963). 'Type of life cycle, growth rate, life form and various environmental factors are also important. Limited field observations suggest that the same morphological characteristies facilitating survival after burning also confer resistance to ionizing radiation. The objective of this study was comparison of the effects of fire and ionizing radiation on two ericaceous species of a shrub community common in eastern North America.

Opportunity for the study arose as part of the Brookhaven Irradiated Forest Experiment in which an oak-pine forest is being irradiated chronically with gamma radiation (Woodwell, 1963). The forest is s milar to the oak-pine forests common on certain coastal plain sands in New Jersey, New York, and New England. These forests have de-

\footnotetext{
${ }^{1}$ Received for publication September 7, 1965.

A portion of the re earch was carried out at Brookhaven National Laboratory under the auspices of the U.S. Atomic Energy Commission.
}

veloped under frequent burning and appear to be particulary well adapted to fire. Both of the dominant shrubs, Gaylussacia baccata and Vaccinium vacillans, sprout readily in response to fire and apparently thrive under its influence if damage is neither frequent nor severe.

In the pine region of New Jersey burning more than once every 5 years increases the relative abundance of Vaccinium vacillans and depresses Gaylussacia baccata, although absolute stem densities of both species are reduced (Buell and Cantlon, 1953). Rebuck (1964) has reported parallel changes in shrub layer structure and composition caused by ionizing radiation (Fig. 1). He has also reported a decline in abundance of Vaccinium. vacillans at high chronic exposures. The parallel between the effects of fire and radiation extends still further to an increase in the cover of Carex pensylvanica under intense irradiation and under frequent burning (Rebuck, 1964).

Thus fire and ionizing radiation appear to have similar effects on structure and composition of the shrub layer. That such a parallel should exist is surprising, since there is no basis for believing that ionizing radiation has played any role in the selective processes of evolution, at least in higher plants. 